\title{
The Effect of UV-B Radiation on the Antioxidant System in the Peltigera aphthosa and Peltigera rufescens Lichens
}

\author{
Mikhail A. Shelyakin*, \\ Ekaterina V. Silina and Tamara K. Golovko \\ Institute of Biology of Komi Scientific Centre \\ of the Ural Branch of RAS \\ Syktyvkar, Russian Federation
}

Received 13.03.2021, received in revised form 11.05.2021, accepted 06.06.2021, published online 12.08.2021

\begin{abstract}
Ultraviolet (UV) radiation is the short wavelength region of the solar spectrum. The high-energy photons of UV-B (280-315 nm) are potentially dangerous for all living organisms. The effect of UV-B radiation on lichens has not been studied sufficiently. We conducted a comparative study of the effects of the long-term (10 d) exposure to the environmentally realistic dose of UV-B radiation on the accumulation of lipid peroxidation products (TBARS), $\mathrm{H}_{2} \mathrm{O}_{2}$ content, superoxide dismutase (SOD) activity, and respiration rate in Peltigera aphthosa from the forest community and Peltigera rufescens from the open spaces of floodplain meadow. The $\mathrm{H}_{2} \mathrm{O}_{2}$ content and the SOD activity were found to increase in the thalli of $P$. rufescens. The TBARS content in the UV-B treated thalli of $P$. rufescens did not differ from the control thalli and was 2.5 times higher than in $P$. aphthosa. In $P$. aphthosa thalli, SOD activity did not change after UV-B exposure, and TBARS content increased by $33 \%$ with an increase in the total UV-B dose. Both lichens exhibited an increase in the alternative respiratory pathway (AP) activity and a decrease in the ratio of the main (cytochrome) pathway to the energy low efficient AP. The AP involvement was more pronounced in $P$. aphthosa. The results of our study indicate the species-specific response in lichens and differences in their resistance to oxidative stress, which were due to adaptation to the light conditions in the typical habitats of these species.
\end{abstract}

Keywords: Peltigera aphthosa, Peltigera rufescens, lichens, UV-B radiation, lipid peroxidation, hydrogen peroxide, superoxide dismutase, alternative respiratory pathway, resistance.

Acknowledgements. This work was carried out as part of the «Physiology and Stress-Resistance of Photosynthesis of Plants and Poikilohydric Photoautotrophs in Conditions of the North» project

(C) Siberian Federal University. All rights reserved

This work is licensed under a Creative Commons Attribution-NonCommercial 4.0 International License (CC BY-NC 4.0).

* Corresponding author E-mail address: shelyakin@ib.komisc.ru

ORCID: 0000-0001-8537-6995 (Shelyakin M.); 0000-0002-9632-3431 (Silina E.); 0000-0002-7993-9541 (Golovko T.) 
(No. AAAA-A17-117033010038-7) funded by the Ministry of Science and Higher Education of the Russian Federation.

Citation: Shelyakin M. A., Silina E. V., Golovko T.K. The effect of UV-B radiation on the antioxidant system in the Peltigera aphthosa and Peltigera rufescens lichens. J. Sib. Fed. Univ. Biol., 2021, 14(3), 328-338. DOI: 10.17516/1997-1389-0359

\title{
Влияние УФ-В-радиации на антиоксидантную систему лишайников Peltigera aphthosa и Peltigera rufescens
}

\author{
М. А. Шелякин, Е. В. Силина, Т. К. Головко \\ Институт биологии Коми научного иентра \\ Уральского отделения РАН \\ Российская Федерация, Сыктывкар
}

\begin{abstract}
Аннотация. Ультрафиолетовая (УФ) радиация относится к коротковолновой части солнечного спектра. Высокоэнергетические фотоны УФ-В-излучения (280-315 нм) потенциально опасны для всех живых клеток. Реакция лишайников на УФ-В-излучение исследована недостаточно. Мы провели сравнительное изучение влияния длительного действия экологически обоснованной дозы УФ-В-радиации на накопление продуктов перекисного окисления липидов (ПОЛ), содержание $\mathrm{H}_{2} \mathrm{O}_{2}$, активность супероксиддисмутазы (СОД) и дыхание талломов Peltigera aphthosa из лесного сообщества и Peltigera rufescens, обитающей на хорошо инсолируемых участках пойменного луга. Выявили повышение содержания $\mathrm{H}_{2} \mathrm{O}_{2}$ и активности СОД в талломах P. rufescens, экспонированных к УФ-В. Содержание продуктов ПОЛ в импактных талломах P. rufescens не отличалось от контроля и было в 2,5 раза выше по сравнению с P. aphthosa. Уровень активности СОД в талломах P. aphthosa не изменялся, но содержание продуктов ПОЛ возрастало на 33 \% с увеличением суммарной дозы УФ-В. У обоих видов лишайников отмечали повышение активности альтернативного пути (АП) дыхания, что приводило к изменению соотношения основного (цитохромного) и энергетически малоэффективного АП. Вовлечение АП было сильнее выражено у P. aphthosa. Результаты исследования свидетельствуют о видовой специфичности реакции лишайников на воздействие УФ-В-излучения, а также указывают на различия в их устойчивости к окислительному стрессу, обусловленные приуроченностью видов к местообитаниям с разным режимом освещенности.
\end{abstract}

Ключевые слова: Peltigera aphthosa, Peltigera rufescens, лишайники, УФ-В-радиация, перекисное окисление липидов, пероксид водорода, супероксиддисмутаза, альтернативный путь дыхания, устойчивость.

Благодарности. Работа выполнена в рамках темы «Физиология и стрессоустойчивость фотосинтеза растений и пойкилогидрических фотоавтотрофов в условиях Севера»

$$
-329-
$$


(№ AАAА-A17-117033010038-7) при финансовой поддержке Министерства науки и высшего образования Российской Федерации.

Цитирование: Шелякин, М.А. Влияние УФ-В-радиации на антиоксидантную систему лишайников Peltigera aphthosa и Peltigera rufescens / М. А. Шелякин, Е. В. Силина, Т. К. Головко // Журн. Сиб. федер. ун-та. Биология, 2021. 14(3), 328-338. DOI: 10.17516/1997-1389-0359

\section{Introduction}

Lichens are a stable self-regulating association of heterotrophic mycobionts with photoautotrophic green algae and/or cyanoprokaryotes. The mycobiont accounts for over $90 \%$ of the thallus biomass and most of the respiration (Palmqvist et al., 2008). The symbiotic nature and poikilohydric properties of lichens ensure that these organisms have high resistance to adverse environmental stresses (Kranner et al., 2005). Due to this, lichens occupy various stressful terrestrial habitats, including deserts, highlands, Arctic and Antarctic regions, and high stress microhabitats in less stressful habitats.

Of the sun ultraviolet (UV) radiation spectrum, only near-UV-A radiation (315-400 $\mathrm{nm}$ ) and a small portion of UV-B photons (280-315 nm) reach the Earth's surface. The high-energy UV-B photons can damage biologically important macromolecules and induce oxidative stress in the cells of living organisms (Frohnmeyer, Staiger, 2003). Adaptive (architecture modification, synthesis of a range of secondary metabolites) and nonspecific harmful (damage to DNA, proteins and membranes, inhibition of photosynthesis and growth, accumulation of reactive oxygen species (ROS)) effects of UV-B radiation on plants have been well-documented (Caldwell et al., 1995, 2003; Jenkins, 2009). Fewer data are available on the effects of UV-B on lichens. High doses of UV-B radiation are known to induce programmed cell death (Ünal, Uyanikgil, 2011) and suppress the growth of lichen thalli (Chowdhury et al., 2017). Different secondary lichen compounds synthesized by the mycobiont play an important role in protecting the lichen photobiont against excessive visible light and UV radiation (Nguyen et al., 2013). UV-B induces the synthesis of parietin and melanins in the thalli of some lichen species (Solhaug et al., 2003; Nybakken et al., 2004; Solhaug, Gauslaa, 2012; Mafole et al., 2019). These compounds are synthesized in the thallus upper cortex cells and absorb or reflect $\mathrm{UV}(\mathrm{A}+\mathrm{B})$ rays, thereby shielding the underlying layers of cells.

Most lichen species in the Komi Republic grow in forest communities. The boreal species often prefer shaded and moist habitats. In the forest, lichens are rarely exposed to the direct sunlight. Such lichens can serve as a convenient model for studying the adverse effects of UV-B radiation. For comparison, lichens from the open habitats, which are exposed constantly to UV radiation, are of great interest for studying protective mechanisms against the UV-B impact. We hypothesized that these species differ considerably in their antioxidant system activity and protective reactions to oxidative stress. To test this idea, we conducted a comparative study of the UV-B effects on the activity of the key antioxidant enzyme - superoxide dismutase (SOD), the $\mathrm{H}_{2} \mathrm{O}_{2}$ content, and the level of lipid peroxidation in Peltigera aphthosa (L.) Willd. and Peltigera rufescens (Weiss) Humb. These lichen species grow in different types of habitats. The effect of UV-B on the respiration rate and the ratio of the cytochrome pathway to the alternative respiratory pathway was studied also to estimate changes in lichen metabolism. 


\section{Materials and methods}

Lichens

P. aphthosa is a foliose lichen with a circumpolar distribution. It is found in the Arctic, boreal, and temperate zones. The lichen grows on moss, soil, and plant debris in shaded and moist sites (Thomson, 1984). The main photobiont of $P$. aphthosa is the green algae of the Pseudococcomyxa genus. The cephalodia on the thallus surface contain cyanoprokaryotes of the genus Nostoc.

P. rufescens is a foliose cyanolichen. Its thallus contains cyanobacteria of the Nostoc genus. This species has a polyzonal distribution and grows in the temperate and boreal latitudes of the Northern hemisphere and in South America and Australia, in fully sunlit habitats, on the open sites in the fields and roadsides (Brodo et al., 2001).

\section{Sampling sites}

The study was conducted in the summer of 2018. P. aphthosa thalli were collected in a pine-dominated forest mixed with spruce and deciduous trees, in shaded and moist places. The thalli of $P$. rufescens were collected in open, well-lit areas of meadows adjacent to the river Vym floodplain. The meadow soil was a well-drained sod-layered sandy loam.

Lichen samples were collected at midday, during clear sunny weather. Simultaneously with sampling, the photosynthetic active radiation (PAR) intensity, air temperature, and relative humidity were measured using a portable weather station (Data Logger LI-1400, U.S.A.). The intensity of near-UV (UV-A and UV-B) radiation was determined using a UV radiometer (TKA-PKM 12, Russia). The thalli were cleaned to remove substrate residues and transported to the laboratory, where air-dry thalli were stored in the dark at $4{ }^{\circ} \mathrm{C}$.

\section{Experiment design}

Before starting the UV radiation treatment, the thalli were moistened and kept for $3 \mathrm{~d}$ under fluorescent lamps (Philips TL-D Aquarelle) at 80 $\mu \mathrm{mol} \mathrm{m} \mathrm{m}^{-2} \mathrm{~s}^{-1}\left(10 / 14 \mathrm{~h}\right.$ photoperiod, $\left.25^{\circ} \mathrm{C}\right)$. After that, the thalli were exposed to UV from lamps (LER40, Russia) for $10 \mathrm{~d}\left(2 \mathrm{~h} \mathrm{~d}^{-1}\right)$. The peak emission spectrum of the lamp was $315 \mathrm{~nm}$ and the UV-B irradiation intensity was $2 \mathrm{~W} \mathrm{~m}^{-2}$. Consequently, the thalli of lichens received about $14 \mathrm{~kJ} \mathrm{~d}^{-1}$ of the UV-B light. That was an environmentally realistic dose, corresponding to the daily dose of UV-B radiation that reaches open ground in this region on a sunny summer day.

The effect of UV-B treatment on thalli was analyzed after 1,3 , and $10 \mathrm{~d}$, which corresponded to the total dose of UV-B radiation of 14,43 , and $144 \mathrm{~kJ}$, respectively. The control thalli were not treated with UV radiation.

\section{Biochemical analyses}

The level of lipid peroxidation was estimated according to the method of Heath and Packer (1968) by assaying the thiobarbituric acid reactive substances (TBARS). The concentration of $\mathrm{H}_{2} \mathrm{O}_{2}$ was measured using the method of Bellincampi et al. (2000). The activity of SOD was determined by its ability to inhibit the photochemical reduction of nitroblue tetrazolium (Beauchamp, Fridovich, 1971). The protein content was determined according to the method of Bradford (1976) with bovine serum albumin taken as the standard.

The respiration rate $\left(\mathrm{V}_{\text {total }}\right)$ was determined by performing the polarographic measurement of $\mathrm{O}_{2}$ uptake using the Oxytherm System Clark electrode (Hansatech Instruments, U.K.). The marginal regions of the lichen thalli were used. The cytochrome $\left(\mathrm{V}_{\text {cyt }}\right)$ and alternative respiratory capacities $\left(\mathrm{V}_{\text {alt }}\right)$ and their ratio were estimated using specific inhibitors (Bahr, Bonner, 1973). The inhibitors $-6 \mathrm{mM}$ benzhydroxamic acid (Lancaster, U.K.) and $2 \mathrm{mM} \mathrm{KCN} \mathrm{(Sigma} \mathrm{Aldrich,}$ 
St. Louis, MO, U.S.A.) - were added successively after measuring the total $\mathrm{O}_{2}$ uptake rate.

\section{Statistical analysis}

The results are presented as means with standard errors (SE) of $n(n=3-8)$ for the control and for samples exposed to each UV-B dose. After checking for normal distribution of variables (Shapiro-Wilk's test), data were analyzed using one-way ANOVA followed by post hoc multiple range testing (Duncan's test, $P<0.05$ ). Tests were conducted using Statistica 10.0 software (StatSoft. Inc., U.S.A.).

\section{Results}

Microclimatic conditions at the sample sites

The habitats of the lichens studied in the present work differed in the amount and quality of light (Table 1). In sunny weather, P. rufescens thalli in the meadow were exposed to PAR intensity that was 5 times higher and $\mathrm{UV}(\mathrm{A}+\mathrm{B})$ intensity that was one order of magnitude higher compared to P. aphthosa in the forest. In the meadow, the air warmed up to an average of $31{ }^{\circ} \mathrm{C}$, while in the forest, the air temperature was $10^{\circ} \mathrm{C}$ lower.

\section{Level of lipid peroxidation}

The widely used thiobarbituric acidreactive-substances (TBARS) assay measures free malondialdehyde (MDA). MDA is largely the product of peroxidation of fatty acids with more than two double bonds. We found that the content of TBARS in the control thalli of $P$. rufescens was 3 times greater than in $P$. aphthosa (Table 2) indicating that UV-B exposure increased fatty acid peroxidation in a species-specific way. After $3 \mathrm{~d}$, the TBARS content in P. aphthosa increased by $33 \%$ compared with the control and did not change after that, until the end of the

Table 1. Spot measurement of the microhabitat conditions in the lichen sampling sites (means \pm SE, $n=6-8$ )

\begin{tabular}{lcc}
\hline \multicolumn{1}{c}{ Parameter } & Meadow & Forest \\
\hline PAR, $\mu$ mol photons $\left(\mathrm{m}^{-2} \mathrm{~s}^{-1}\right)$ & $1461 \pm 42$ & $311 \pm 18$ \\
Intensity of $\mathrm{UV}(\mathrm{A}+\mathrm{B})$ radiation, $\mathrm{W} \mathrm{m}^{-2}$ & $26.9 \pm 0.5$ & $1.4 \pm 0.1$ \\
$\mathrm{~T}_{\text {air }},{ }^{\circ} \mathrm{C}$ & $31.1 \pm 0.3$ & $21.2 \pm 0.4$ \\
$\mathrm{RH}, \%$ & $35.7 \pm 2.3$ & $40.3 \pm 1.4$ \\
\hline
\end{tabular}

Table 2. Lipid peroxidation level and $\mathrm{H}_{2} \mathrm{O}_{2}$ content in the thalli exposed to UV-B radiation

\begin{tabular}{ccccc}
\hline $\begin{array}{c}\text { Total dose } \\
\text { of UV-B, kJ (day) }\end{array}$ & $\begin{array}{c}\text { Peltigera aphthosa } \\
\text { TBARS, } \\
\text { nmol g-1 DW }\end{array}$ & $\begin{array}{c}\mathrm{H}_{2} \mathrm{O}_{2}, \\
\mu \mathrm{mol} \mathrm{g}^{-1} \mathrm{DW}\end{array}$ & $\begin{array}{c}\text { Peltigera rufescens } \\
\text { TBARS, }\end{array}$ & $\begin{array}{c}\mathrm{H}_{2} \mathrm{O}_{2}, \\
\mathrm{nmol} \mathrm{g}^{-1} \mathrm{DW}\end{array}$ \\
\hline Control & $150.0 \pm 3.2^{\mathrm{a}}$ & $41.4 \pm 3.0^{\mathrm{a}}$ & $464.7 \pm 9.2^{\mathrm{a}}$ & $36.0 \pm 1.4^{\mathrm{c}}$ \\
$14(1)$ & $143.7 \pm 3.3^{\mathrm{a}}$ & $40.5 \pm 1.1^{\mathrm{a}}$ & $487.5 \pm 9.3^{\mathrm{a}}$ & $42.3 \pm 1.8^{\mathrm{a}}$ \\
$43(3)$ & $196.0 \pm 7.0^{\mathrm{b}}$ & $50.7 \pm 1.3^{\mathrm{c}}$ & $540.6 \pm 21.8^{\mathrm{b}}$ & $48.5 \pm 1.5^{\mathrm{b}}$ \\
$144(10)$ & $196.2 \pm 6.2^{\mathrm{b}}$ & $30.3 \pm 0.5^{\mathrm{b}}$ & $473.9 \pm 3.9^{\mathrm{a}}$ & $43.7 \pm 1.8^{\mathrm{ab}}$ \\
\hline
\end{tabular}

Lipid peroxidation products (TBARS) and $\mathrm{H}_{2} \mathrm{O}_{2}$ content are presented as means $\pm \mathrm{SE}(\mathrm{n}=3-4)$. Significant differences between values depending on total UV-B dose are indicated by different superscript letters (one-way ANOVA, Duncan test, $P<0.05$ ). DW - dry weight. 
experiment. By contrast, in $P$. rufescens, after $3 \mathrm{~d}$, the TBARS content was only $16 \%$ higher than in the control but did not differ from the control after $10 \mathrm{~d}$.

\section{Hydrogen peroxide content}

The lichen species did not significantly differ in the hydrogen peroxide levels (Table 2). The maximum accumulation of $\mathrm{H}_{2} \mathrm{O}_{2}\left(48-50 \mu \mathrm{mol} \mathrm{g}^{-1}\right.$ DW) in the thalli of both lichen species occurred after $3 \mathrm{~d}$, and it was 20-25\% higher than in the control. The $\mathrm{H}_{2} \mathrm{O}_{2}$ content decreased by $40 \%$ in $P$. aphthosa and did not change in $P$. rufescens after $10 \mathrm{~d}$ of UV-B exposure.

\section{Superoxide dismutase activity}

The control thalli of $P$. aphthosa and P. rufescens showed similar levels of SOD activity (Table 3). The UV-B treatment did not affect the SOD activity in $P$. aphthosa thalli. We observed a significant increase in the SOD activity in $P$. rufescens thalli after 3 and 10 days of the UV-B exposure. After $10 \mathrm{~d}$ of UV-B treatment, the enzyme activity in the thalli of $P$. rufescens was $35 \%$ higher than in the control.

\section{Respiration}

Total $\mathrm{O}_{2}$ uptake rate in the control and UV-treated thalli of $P$. rufescens was more than 1.5 times higher than in $P$. aphthosa (Table 4). UV-B radiation significantly affected the total $\mathrm{O}_{2}$ uptake rate and the proportions of the activities of the respiratory pathways. A decrease in total $\mathrm{O}_{2}$ uptake rate and in cytochrome pathway (CP) activity was observed immediately after $1 \mathrm{~d}$ in both species. The alternative pathway (AP) capacity increased and the CP/AP ratio decreased by 2.5 times compared to the control samples. After $3 \mathrm{~d}$, total $\mathrm{O}_{2}$ uptake increased, but the $\mathrm{CP} / \mathrm{AP}$

Table 3. Superoxide dismutase activity (units $\mathrm{mg}^{-1}$ protein) in the thalli exposed to UV-B radiation

\begin{tabular}{ccc}
\hline Total dose of UV-B, kJ (day) & Peltigera aphthosa & Peltigera rufescens \\
\hline Control & $12.2 \pm 0.3^{\mathrm{a}}$ & $11.1 \pm 0.3^{\mathrm{a}}$ \\
$14(1)$ & $11.9 \pm 0.2^{\mathrm{a}}$ & $11.0 \pm 0.2^{\mathrm{a}}$ \\
$43(3)$ & $12.0 \pm 0.2^{\mathrm{a}}$ & $12.8 \pm 0.3^{\mathrm{b}}$ \\
$144(10)$ & $11.8 \pm 0.1^{\mathrm{a}}$ & $17.3 \pm 0.5^{\mathrm{c}}$ \\
\hline
\end{tabular}

Enzyme activity is presented as means $\pm \mathrm{SE}(\mathrm{n}=3-4)$. Other designations as in Table 2.

Table 4. Influence of UV-B radiation on the total respiration rate and the activities of the cytochrome and alternative respiratory pathways in lichen thalli ( $\left.\mathrm{nmol} \mathrm{O}_{2} \mathrm{~g}^{-1} \mathrm{DW} \mathrm{min}^{-1}\right)$

\begin{tabular}{ccccc}
\hline \multirow{2}{*}{$\begin{array}{c}\text { Total dose } \\
\text { of UV-B, kJ (day) }\end{array}$} & \multicolumn{2}{c}{ Peltigera aphthosa } & \multicolumn{2}{c}{ Peltigera rufescens } \\
\cline { 2 - 5 } & $V_{\text {total }}$ & $V_{\text {cyt }} / V_{\text {alt }}$ & $V_{\text {total }}$ & $V_{\text {cy }} / V_{\text {alt }}$ \\
\hline Control & $939 \pm 39^{\mathrm{b}}$ & $3.6 \pm 0.7^{\mathrm{b}}$ & $1306 \pm 56^{\mathrm{a}}$ & $3.3 \pm 0.5^{\mathrm{b}}$ \\
$14(1)$ & $740 \pm 34^{\mathrm{a}}$ & $1.3 \pm 0.2^{\mathrm{ab}}$ & $1153 \pm 7^{\mathrm{ab}}$ & $1.5 \pm 0.2^{\mathrm{a}}$ \\
$43(3)$ & $1042 \pm 39^{\mathrm{b}}$ & $1.3 \pm 0.3^{\mathrm{ab}}$ & $1343 \pm 51^{\mathrm{a}}$ & $1.4 \pm 0.1^{\mathrm{a}}$ \\
$144(10)$ & $660 \pm 47^{\mathrm{a}}$ & $0.9 \pm 0.1^{\mathrm{a}}$ & $1069 \pm 73^{\mathrm{b}}$ & $1.3 \pm 0.1^{\mathrm{a}}$ \\
\hline
\end{tabular}

$\mathrm{O}_{2}$ uptake rate $\left(V_{\text {total }}\right)$, cytochrome and alternative respiratory pathway activities ratio $\left(V_{\text {cyt }} / V_{\text {alt }}\right)$ are presented as means $\pm \mathrm{SE}$ $(\mathrm{n}=5-15)$. Other designations as in Table 2. 
ratio did not change. After $10 \mathrm{~d}$, total $\mathrm{O}_{2}$ uptake rate was $35 \%$ lower than after $3 \mathrm{~d}$ and $30 \%$ lower than in the control thalli of P. aphthosa. The decrease in $P$. rufescens respiration rate was less pronounced. The value of $\mathrm{CP} / \mathrm{AP}$ ratio remained low in both species.

In the control thalli of both species, the proportion of $\mathrm{CP}$ accounted for more than $60 \%$ of the total respiration rate (Figure). The contribution of AP to total $\mathrm{O}_{2}$ uptake was only
$20 \%$. Increased involvement of the low energy effective alternative pathway and a decrease in the main (cytochrome) pathway contribution to the total respiration were observed in UV-B treated thalli. The $\mathrm{CP}$ contribution decreased on average by 1.4 times and the AP contribution doubled after $10 \mathrm{~d}$ of exposure to UV-B radiation. The contributions of AP to the total respiration of $P$. aphthosa and $P$. rufescens thalli were $44 \%$ and $35 \%$, respectively.

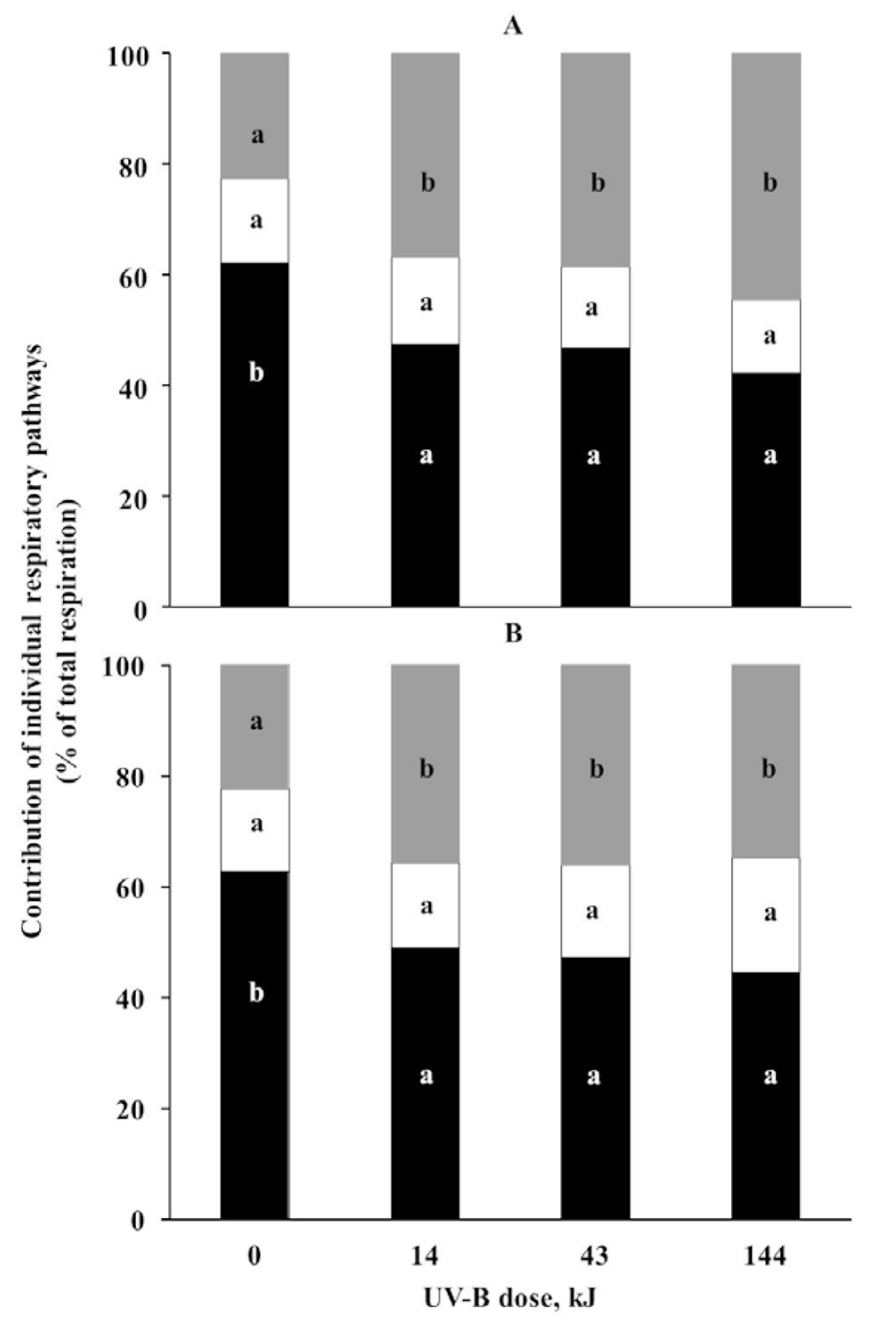

Figure. Effect of UV-B radiation on the relative contribution of each respiratory pathway to total respiration in the lichens A) Peltigera aphthosa and B) Peltigera rufescens. The contributions of the cytochrome (black) and alternative pathways (grey) and residual respiration (white) to total respiration are shown. Different letters in each column indicate significant differences between the control and different UV-B doses (one-way ANOVA, Duncan test, $P<0.05$ ). 0 - Control samples without UV-B exposure. 14, 43, 144 - The total dose of UV-B radiation received by thalli on the first, third and tenth days of exposure, respectively 


\section{Discussion}

The aim of this work was to obtain information on the effects of UV-B radiation on the metabolism of $P$. aphthosa and P. rufescens. In nature, the lichen thalli grow at different levels of insolation and temperature (Table 1). High insolation, especially the high-energy shortwavelength photons, increases the generation of ROS, which causes oxidative stress in living cells. The effect of high-energy photons on lichens depends on their state. It is believed that ROS can attack membrane lipids, proteins, and other biologically significant molecules in the wet lichens. The dry lichens are inactive and resistant to extreme conditions. They retained their vital functions even after exposure to open space conditions (De Vera et al., 2008; Sánchez et al., 2014). However, Cladonia arbuscula ssp. mitis (Sandst.) Ruoss was sensitive to UV-B irradiation in the air-dried state and was not able to completely repair the DNA damage (Buffoni Hall et al., 2003). Furthermore, temperature and light intensity played a role in the capacity of the lichen to self-repair the damage.

Our results show that the two lichens studied here exhibited different physiological responses to an environmentally realistic dose of UV-B. We found that $P$. rufescens thalli had a higher TBARS content but accumulated considerably smaller amounts of lipid peroxidation products under UV-B treatment compared to P. aphthosa (Table 2). This is most likely due to the adaptation of $P$. rufescens to brighter light and higher temperature conditions in its microhabitat. However, interestingly, an increase in $\mathrm{H}_{2} \mathrm{O}_{2}$ content in $P$. rufescens thalli was observed shortly after exposure to UV-B light while in $P$. aphthosa, the $\mathrm{H}_{2} \mathrm{O}_{2}$ content increased significantly only after $3 \mathrm{~d}$, when the total UV-B dose was around $40 \mathrm{~kJ}$.

The control thalli of both species did not differ in SOD activity. SOD is highly efficient in catalytic removal of the superoxide radical $\left(\mathrm{O}_{2}{ }^{--}\right)$. SOD catalyzes the dismutation of $\mathrm{O}_{2}{ }^{--}$to $\mathrm{H}_{2} \mathrm{O}_{2}$ and $\mathrm{O}_{2} \cdot \mathrm{H}_{2} \mathrm{O}_{2}$ is a relatively stable compound, which regulates many cell processes. We did not find a direct relationship between changes in the SOD activity and the content of $\mathrm{H}_{2} \mathrm{O}_{2}$ following UV-B exposure. The UV-B treatment had no effect on SOD activity in $P$. aphthosa thalli. Rehydration of desiccated lichens did not cause any response or decrease in SOD activity (Weissman et al., 2005). A «burst-like» formation of ROS and, in particular, the superoxide radical, was observed in lichens after a long desiccation period (Beckett et al., 2003). Probably, any upregulation of SOD during rehydration was suppressed due to inactivation by high ROS concentrations in thalli. The increase in TBARS content in P. aphthosa thalli was probably a result of the accumulation of ROS. Lichens can contain from six to ten $\mathrm{Fe}-, \mathrm{Cu} /$ $\mathrm{Zn-}$, and Mn-SOD isoforms (Schlee et al., 1995; Weissman et al., 2005). UV could have different effects on the activity of different SOD isoforms, which resulted in the absence of the pronounced effect on the total SOD activity. A significant increase in the SOD activity in P. rufescens thalli was observed after $3 \mathrm{~d}$ of the treatment. SOD activity was maximal after $10 \mathrm{~d}$ of exposure, when the total UV-B dose reached $144 \mathrm{~kJ}$, indicating that UV-B increased the capacity of this species to dismutate $\mathrm{O}_{2}{ }^{--}$into more stable $\mathrm{H}_{2} \mathrm{O}_{2}$. A more rapid conversion of $\mathrm{O}_{2}{ }^{--}$to $\mathrm{H}_{2} \mathrm{O}_{2}$ can contribute to a more successful defense of cells from the most active ROS. At the same time, an increase in the $\mathrm{H}_{2} \mathrm{O}_{2}$ content also contributes to the development of oxidative stress, and future work needs to focus on the effect of UV-B on the enzymes, such as catalase, that metabolize $\mathrm{H}_{2} \mathrm{O}_{2}$.

Respiration is a crucial process that provides all living organisms with energy and metabolites for growth and cellular maintenance.

We found that UV-B treatment had a significant effect on the total respiration rate and $\mathrm{CP} / \mathrm{AP}$ 
ratio in the thalli of both lichen species studied here (Table 4). The activity and proportion of AP in total respiration increased, whereas the contribution of $\mathrm{CP}$ decreased (Figure), suggesting that the UV-B treatment activated the energy dissipation processes. The effect of UV-B on the respiratory pathway ratio was more pronounced in $P$. aphthosa than in $P$. rufescens. We noted the same reaction to UV-B in Cladonia stellaris (Opiz) Pouzar \& Vezda (Shelyakin et al., 2018). The change in the ratio of the respiratory pathways in UV-B treated lichens is probably a common event. The activation of AP may prevent an excessive reduction in the mitochondrial electron transport chain and the development of oxidative stress in cells. The role of the alternative respiratory pathway as a component of the ROS-scavenging system in lichens has already been discussed by other researchers (Beckett et al., 2008). Since the fungal component accounts for more than $90 \%$ of the lichen thalli, we assume that the mycobiont is the main cause of the changes in the ratios of the respiratory pathways found here. The question of the contribution of mycobiont and different types of photobiont to the total respiration, peroxide accumulation, and the activity of antioxidant enzymes in lichens needs further investigation.

\section{Conclusion}

The results demonstrate that the response to UV-B radiation of the antioxidant system and respiration of lichens is species-specific. $P$. rufescens, growing in the open habitat, accumulates greater amounts of products of lipid oxidation and has a higher rate of respiration than $P$. aphthosa, the species from the more shaded forest habitat. This may indicate that $P$. rufescens thalli experience a higher oxidative stress under normal field conditions. Exposure to UV-B of P. rufescens thalli increased SOD activity, while in $P$. aphthosa, UV radiation did not affect SOD activity but increased lipid peroxidation. Thus, the tolerance to oxidative stress of the two species is different, probably because of the dissimilarities in the temperature and light conditions in typical habitats of these species. However, in both species, particularly in $P$. aphthosa, UV-B increased the activity and contribution of energy dissipative alternative respiratory pathway. Such changes in respiration are likely a universal response of lichens to the oxidative stress.

\section{References}

Bahr J. T., Bonner W.D. (1973) Cyanide-insensitive respiration. I. The steady states of skunk cabbage spadix and bean hypocotyl mitochondria. Journal of Biological Chemistry, 248(10): 34413445

Beauchamp C., Fridovich I. (1971) Superoxide dismutase: Improved assays and an assay applicable to acrylamide gels. Analytical Biochemistry, 44(1): 276-287

Beckett R.P., Kranner I., Minibayeva F. V. (2008) Stress physiology and the symbiosis. Lichen Biology. Nash T.H. (ed.) Cambridge, Cambridge University Press, p. 134-151

Beckett R.P., Minibayeva F. V., Vylegzhanina N.N., Tolpysheva T. (2003) High rates of extracellular superoxide production by lichens in the suborder Peltigerineae correlate with indices of high metabolic activity. Plant, Cell \& Environment, 26(11): 1827-1837

Bellincampi D., Dipierro N., Salvi G., Cervone F., De Lorenzo G. (2000) Extracellular $\mathrm{H}_{2} \mathrm{O}_{2}$ induced by oligogalacturonides is not involved in the inhibition of the auxin-regulated $\mathrm{rolB}$ gene expression in Tobacco leaf explants. Plant Physiology, 122(4): 1379-1385 
Bradford M. M. (1976) A rapid and sensitive method for the quantitation of microgram quantities of protein utilizing the principle of protein-dye binding. Analytical Biochemistry, 72(1-2): 248-254

Brodo I. M., Sylvia D. S., Stephen S. (2001) Lichens of North America. New Haven and London, Yale University Press, 828 p.

Buffoni Hall R. S., Paulsson M., Duncan K., Tobin A. K., Widell S., Bornman J. F. (2003) Waterand temperature-dependence of DNA damage and repair in the fruticose lichen Cladonia arbuscula ssp. mitis exposed to UV-B radiation. Physiologia Plantarum, 118(3): 371-379

Caldwell M. M., Ballare C. L., Bornman J. F., Flint S. D., Bjorn L. O., Teramura A. H., Kulandaivelu G., Tevini M. (2003) Terrestrial ecosystems, increased solar ultraviolet radiation and interactions with other climatic change factors. Photochemical \& Photobiological Sciences, 2(1): 29-38

Caldwell M.M., Teramura A.H., Tevini M., Bornman J.F., Bjorn L. O., Kulandaivelu G. (1995) Effects of increased solar ultraviolet radiation on terrestrial plants. Ambio, 24(3): 166-173

Chowdhury D. P., Solhaug K. A., Gauslaa Y. (2017) Ultraviolet radiation reduces lichen growth rates. Symbiosis, 73(1): 27-34

De Vera J.-P., Rettberg P., Ott S. (2008) Life at the limits: Capacities of isolated and cultured lichen symbionts to resist extreme environmental stresses. Origins of Life and Evolution of Biospheres, 38(5): 457-468

Frohnmeyer H., Staiger D. (2003) Ultraviolet-B radiation-mediated responses in plants. Balancing damage and protection. Plant Physiology, 133(4): 1420-1428

Heath R.L., Packer L. (1968) Photoperoxidation in isolated chloroplasts: I. Kinetics and stoichiometry of fatty acid peroxidation. Archives of Biochemistry and Biophysics, 125(1): 189-198

Jenkins G. I. (2009) Signal transduction in responses to UV-B radiation. Annual Review of Plant Biology, 60(1): 407-431

Kranner I., Cram W. J., Zorn M., Wornik S., Yoshimura I., Stabentheiner E., Pfeifhofer H. W. (2005) Antioxidants and photoprotection in a lichen as compared with its isolated symbiotic partners. Proceedings of the National Academy of Sciences of the United States of America, 102(8): 3141-3146

Mafole T. S., Solhaug K. A., Minibayeva F. V., Beckett R.P. (2019) Occurrence and possible roles of melanic pigments in lichenized ascomycetes. Fungal Biology Reviews, 33(3-4): 159-165

Nguyen K.-H., Chollet-Krugler M., Gouault N., Tomasi S. (2013) UV-protectant metabolites from lichens and their symbiotic partners. Natural Product Reports, 30(12): 1490-1508

Nybakken L., Solhaug K.A., Bilger W., Gauslaa Y. (2004) The lichens Xanthoria elegans and Cetraria islandica maintain a high protection against UV-B radiation in Arctic habitats. Oecologia, 140(2): 211-216

Palmqvist K., Dahlman L., Jonsson A., Nash T. H. (2008) The carbon economy of lichens. Lichen Biology. Nash T.H. (ed.) Cambridge, Cambridge University Press, p. 182-215

Sánchez F. J., Meeßen J., Ruiz M. D.C., Sancho L. G., Ott S., Vílchez C., Horneck G., Sadowsky A., De La Torre R. (2014) UV-C tolerance of symbiotic Trebouxia sp. in the space-tested lichen species Rhizocarpon geographicum and Circinaria gyrosa: role of the hydration state and cortex/screening substances. International Journal of Astrobiology, 13(1): 1-18

Schlee D., Kandzia R., Tintemann H., Türk R. (1995) Activity of superoxide dismutase and malondialdehyde content in lichens along an altitude profile. Phyton, 35(2): 233-242 
Shelyakin M. A., Zakhozhiy I. G., Golovko T. K. (2018) Changes of total respiration and respiratory pathways ratio in lichens adaptation to UV-B radiation. Proceedings of the RAS Ufa Scientific Centre [Izvestia Ufimskogo Nauchnogo Tsentra RAN], 3: 100-104 (in Russian)

Solhaug K. A., Gauslaa Y. (2012) Secondary lichen compounds as protection against excess solar radiation and herbivores. Progress in Botany. Lüttge U., Beyschlag W., Büdel B., Francis D. (eds.) Berlin, Heidelberg, Springer, p. 283-304

Solhaug K.A., Gauslaa Y., Nybakken L., Bilger W. (2003) UV-Induction of sun-screening pigments in lichens. New Phytologist, 158(1): 91-100

Thomson J. (1984) American arctic lichens. I. The macrolichens. New York, Columbia University Press, $504 \mathrm{p}$.

Ünal D., Uyanikgil Y. (2011) UV-B induces cell death in the lichen Physcia semipinnata (J.F. Gmel). Turkish Journal of Biology, 35: 137-144

Weissman L., Garty J., Hochman A. (2005) Characterization of enzymatic antioxidants in the lichen Ramalina lacera and their response to rehydration. Applied and Environmental Microbiology, 71(11): 6508-6514 